\title{
Breast Cancer pT4b TNM Finding v6 and v7
}

National Cancer Institute

\section{Source}

National Cancer Institute. Breast Cancer pT 4b TNM Finding v6 and v7. NCI Thesaurus. Code C48987.

Breast cancer with ulceration and/or ipsilateral satellite nodules and/or edema (including peau d'orange) of the skin, which do not meet the criteria for inflammatory carcinoma. (from AJCC 6th and 7th Eds.) 